Т.В. Смірнова ${ }^{1}$, Д.О. Пархоменко ${ }^{2}$, Р.О. Голубець ${ }^{1}$, А.В. Щербань ${ }^{1}$, Е.К. Багдасарян ${ }^{1}$

${ }^{1}$ Центральноукраӥнський національний технічний університет, Кропивницький

${ }^{2}$ Харківський національний університет Повітряних Сил ім. І. Кожедуба, Харків

\title{
ФОРМАЛІЗАЦІЯ ПРОБЛЕМИ ПІДТРИМКИ ТЕХНОЛОГІЧНИХ ПРОЦЕСІВ У ХМАРНИХ СЕРВICAX
}

У роботі проаналізовано труднощчі автоматизащії проектування технологічних прочесів, пов'язані головним чином з тим, щчо завдання проектування технологічних процесів не мають в даний час формальних методів вирішення. Тому для здійснення технологічного проектування проведено розробку формалізації технології (або ї̈ частини), тобто проведено заміну (перетворення) змістовних пропозицій математичним апаратом. В результаті даної формалізачії запропоновано схему руху інформації в процесі оптимізації технологічного прочесу. Також розроблено модель реалізачії структури технологічного прочесу, для якої визначено основні вхідні параметри: перелік параметрів, які впливають на прочес; перелік параметрів, які $\epsilon$ результатом процесу; перелік керованих параметрів; перелік некерованих параметрів; перелік невідомих параметрів; деталізована структура технологічного процесу з розділенням параметрів та результатів. Таким чином розроблена у даній роботі формалізаџія проблеми підтримки технологічних процесів у хмарних сервісах дозволяє у подальшому оптимізувати високотехнологічні процеси підприємств різного масштабу з використанням хмарних інформаційних технологій.

Ключові слова: система підтримки прийняття рішень, технологічні процеси, хмарні сервіси.

\section{Вступ}

Постановка проблеми. У процесі автоматизації проектування технологічних процесів відбувається переробка великих обсягів інформації. Ефективність процесу проектування багато в чому залежить від раціонального подання вихідної інформаціï, і в першу чергу з точки зору її повноти і надмірності.

Вихідну інформацію для проектування технологічних процесів поділено на базову, керівну і довідкову.

Базова інформація для проектування технологічних процесів включає [1]:

- дані, що містяться в конструкторський документації на виріб;

- програму випуску, що визначає тип виробництва;

- відомості про наявність технологічного оснащення, виробничих площах і т.п. (при проектуванні технологічних процесів для діючих заводів і цехів).

Керівна інформація включає дані, які містяться в наступних джерелах [2]:

- відповідних галузевих стандартах і стандартах підприємства на технологічні процеси, методи управління ними, технологічне оснащення (обладнання, пристосування та ін.);

- документації на перспективні технологічні процеси;

- виробничих інструкціях.
Довідкова інформація включає дані, які містяться в [2]:

- документації на діючі типові технологічні процеси по даному виду обробки;

- описах прогресивних методів обробки;

- каталогах, номенклатурних довідниках прогресивного технологічного обладнання і оснастки;

- матеріалах щодо вибору технологічних нормативів (режимів обробки, припусків, норм витрати матеріалів і ін.);

- планах підвищення технічного рівня виробництва;

- методичних матеріалах по керівництву розрахунками точності процесів обробки;

- матеріалах і трудових нормативах (в тому числі машинобудівний і галузевих нормативах часу для нормування технологічної трудомісткості, тарифно-кваліфікаційних довідниках тощо).

Труднощі автоматизації проектування технологічних процесів (ПТП) пов'язані головним чином 3 тим, що завдання ПТП не мають в даний час формальних методів вирішення. Так, завдання вибору маршрутного технологічного процесу при її описовому викладі не містить даних про методи проектування процесів виготовлення складних деталей, які могли б бути представлені математичними операціями, реалізованими у вигляді програмного забезпечення. Крім того, вибір послідовності дій і засобів для виготовлення деталі не може бути виведений математичним чином на основі вихідних даних.

Для сучасних розробок технологічних процесів 
характерно [2]:

- відсутність строгих аналітичних залежностей;

- складна логіка суджень, складний взаємозв'я-

зок і взаємний вплив окремих завдань;

- наявність величезних інформаційних потоків

і великої кількості складових елементів технології (верстати, пристосування, інструмент, режими обробки і ін.);

- застосування хмарних технологій.

Процес "ручного" проектування технологічних процесів є послідовністю дій, за допомогою яких інженер-технолог виробляє вибір елементів 3 розглянутих масивів різних технологічних предметів, встановлює між ними відповідності, формуючи переходи і технологічні операції. Вибір оптимального процесу проводиться технологом шляхом порівняння варіантів процесів при введенні оцінок на елементи, його складові.

Рішення будь-якої задачі за допомогою комп'ютерної техніки вимагає наявності аналітичних або інших видів залежностей, що відображають кількісний, а не якісний бік процесу проектування. Тому для здійснення технологічного проектування необхідно провести формалізацію технології (або іiі частини), тобто провести заміну (перетворення) змістовних пропозицій математичним апаратом.

В статті метою формалізації $\epsilon$ забезпечення можливості створення універсальних алгоритмів i програм щодо початкових і кінцевих умов, тобто щодо форми і розмірів деталей, характеру виробництва, характеристик устаткування і оснащення, проектуванні різних технологічних процесів для деталей різних класів і будь-якої складності й їх реалізація у вигляді хмарного сервісу.

Аналіз останніх досліджень і публікацій. Формалізація завдання перетворює процес технологічного проектування 3 процесу міркувань і побудови аналогій в процес суворого розрахунку [1-8]. При цьому форма побудови технологічного процесу i його складових елементів може бути виражена за допомогою апарату математичної логіки, зміст технологічних процесів, що характеризується рядом властивостей об'єктів технології, описано засобами теорії множин, а якісні співвідношення представлені кількісними залежностями за допомогою логічних функцій. У роботах $[1 ; 6]$ розглянуто хмарну автоматизовану систему інтелектуальної підтримки прийняття рішень для технологічних процесів, та визначено область застосування таких систем. Роботи $[2 ; 7 ; 12 ; 14 ; 16]$ обгрунтовують застосування систем підтримки прийняття рішень для реалізації технологічних процесів. Використання у задачах даного класу експертних систем обгрунтовано у роботах $[3 ; 5 ; 15 ; 16]$. Опис технологічних операцій для різних технологічних процесів наведено у роботах $[4 ; 7 ; 10 ; 13]$. Формування баз даних та баз знань для відповідних систем обгрунтовані у роботах [5; 8]. Таким чином проведений аналіз підтверджує необхідність формалізації проблеми підтримки технологічних процесів у хмарних сервісах, для практичного застосування у розроблювальних у подальшому системах підтримки прийняття рішень при автоматизації процесів формування та відновлення деталей.

Мета статті - полягає в формалізації проблеми підтримки технологічних процесів у хмарних сервісах, що дозволить у подальшому оптимізувати високотехнологічні процеси підприємств різного масштабу з використання хмарних інформаційних технологій.

\section{Виклад основного матеріалу}

\section{Принципи формалізації завдання вибору}

Проектування i оптимізація технологічних процесів є складним завданням, оскільки вимагає врахування великої кількості факторів, що впливають на результати процесу. Велике число факторів не дозволяє отримати строгі функціональні залежності для вибору методу і розрахунку оптимальних технологічних параметрів. Це завдання може бути вирішено двома шляхами.

Перший шлях - застосування типових технологічних рішень. На практиці, з метою забезпечення вибору методу обробки користуються переліком методів, застосовуваних для обробки типових поверхонь або типових деталей. При цьому звужується кількість груп розглянутих методів, але необхідна подальша конкретизація критеріїв для подальшого звуження кола об'єктів вибору.

Другий шлях - створення автоматизованого банку методів оптимізації для пошуку і вибору 3 використанням цифрових технологій. Під таким банком маються на увазі всі цифрові бази даних відомі методи оптимізації технологічних процесів 3 перерахуванням їх технологічних параметрів і також стандартні програми, що допускають оновлення i необхідну обробку наявної інформації.

Нехай є деякий набір методів, які використовуються в якості виробничих процесів $M_{1}, M_{2}, M_{3}, \ldots, M_{i}, \ldots, M_{n}\left(M_{i}-i\right.$-й тип метода обробки). Для кожного з цих методів, що належать до зазначеної групи $\left[M_{i}\right]_{i}^{n}=1$, відомий набір технологічних параметрів, що досягаються цим методом:

$$
\begin{array}{ll}
M_{1}: & X_{1}^{(1)}, X_{2}^{(1)}, X_{3}^{(1)}, \ldots, X_{j}^{(1)}, \ldots, X_{m}^{(1)} ; \\
M_{2}: & X_{1}^{(2)}, X_{2}^{(2)}, X_{3}^{(2)}, \ldots, X_{j}^{(2)}, \ldots, X_{m}^{(2)} ; \\
M_{i}: & X_{1}^{(i)}, X_{2}^{(i)}, X_{3}^{(i)}, \ldots, X_{j}^{(i)}, \ldots, X_{m}^{(i)} ; \\
M_{n}: & X_{1}^{(n)}, X_{2}^{(n)}, X_{3}^{(m)}, \ldots, X_{j}^{(n)}, \ldots, X_{m}^{(n)} ;
\end{array}
$$


У просторі параметрів $\left[X_{j}\right]_{j}^{m}=1$ кожному методу $\left[M_{i}\right]_{i}^{n}=1$ буде відповідати точка $M_{i} 3$ координатами:

$$
X_{1}^{(i)}, X_{2}^{(i)}, X_{3}^{(i)}, \ldots, X_{j}^{(i)}, \ldots, X_{m}^{(i)} .
$$

Позначимо задані числові характеристики параметрів технологічного процесу через:

$$
X_{1}^{(0)}, X_{2}^{(0)}, X_{3}^{(0)}, \ldots, X_{j}^{(0)}, \ldots, X_{m}^{(0)} .
$$

Тоді ідеальним (еталонним) методом для даної ситуації був би метод $M_{0}$, характеристики якого рівні необхідним параметрам технологічного процесу. У просторі параметрів $\left[X_{j}\right]_{j}^{m}=1$ цьому методу буде відповідати точка $M_{0}$, рис. 13 координатами: $X_{1}^{(0)}, X_{2}^{(0)}, X_{3}^{(0)}, \ldots, X_{j}^{(0)}, \ldots, X_{m}^{(0)}$

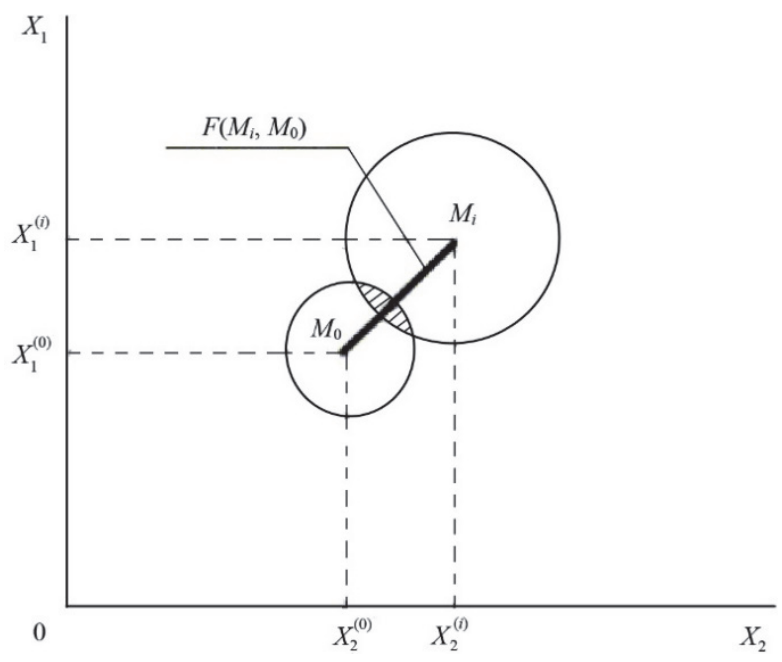

Рис. 1. Схема вибору методу обробки в просторі параметрів $X_{1}, X_{2}$

Джерело: розроблено авторами.

При виборі методу важко забезпечити повний збіг всіх фізико-механічних та інших параметрів із заданими еталонними значеннями. Тому розглянуте завдання зводиться до визначення методу, найближчого за своїми параметрами до еталонного методу $M_{0}$, тобто до задоволення умови близькості: мінімум функціоналу $F\left(M_{i}, M_{0}\right)$.

Процес мінімізації може здійснюватися за кількома типами мінімізуючих функціоналів, наприклад:

$$
F\left(M_{i}, M_{0}\right)=\sqrt{\sum_{j=1}^{m}\left(X_{j}^{(i)}-X_{j}^{(0)}\right)^{2} \rho_{j}},
$$

де $X_{j}^{(i)}$ та $X_{j}^{(0)}$-параметри розглянутого методу обробки та еталонні, необхідні за умовами експлуатації деталі;

$\rho_{j}$-вагові функції, що визначають ступінь важливості параметра.

\section{Облік розсіювання конструкторсько- технологічних параметрів}

У загальному випадку параметри $X_{j}^{(i)}$ та $X_{j}^{(0)}$ представляють випадкові величини і характеризуються математичним очікуванням $\bar{X}_{j}^{(i)}, \bar{X}_{j}^{(0)}$ і дисперсією $\left(\sigma_{x_{j}}^{(i)}, \sigma_{x_{j}}^{(0)}\right)$. Тоді заштрихована область на рис. 1 характеризує ймовірність досягнення необхідних властивостей оброблюваної деталі при застосуванні $i$-го методу.

На практиці зазвичай на найбільш важливі параметри встановлюється номінал в середині поля допуску. Але це інтуїтивне рішення є апріорно оптимальним лише в тому вельми окремому випадку, коли одночасно має місце:

a) симетричний (по відношенню до номіналу) закон розподілу відхилень параметра;

б) однакова (симетрична по відношенню до центру допуску) ціна придатної продукції і однакова вартість продукції, що виходить за межі допуску.

Практично, в дуже великій кількості реальних випадків має місце несиметричний розподіл ціни результату. У всіх цих випадках підлягає дослідженню питання про доцільність зміщення номіналу щодо середини допуску, тобто зміщенні, що створює найбільше математичне сподівання ціни результату.

Метод оптимуму номіналу [9] дозволяє для будь-якого відомого закону розподілу відхилень і заданого розподілу цін результату визначити таке зміщення номіналу від середини поля допуску, яке дає найбільше значення математичного очікування ціни результату - найбільшу інтегральну споживчу ефективність $U^{i}(X)$.

Математичне сподівання $E$ інтегрального показника споживчої цінності $U^{i}(X)$ по кожній $i$-й альтернативі $(i=1,2, \ldots, n)$ за сукупністю показників $X=\left[x_{j}\right]_{j}^{m}=1$ може бути визначено за формулою [10]:

$$
E\left[U^{i}(X)\right]=\frac{1}{K}\left\{\left[\prod_{j=1}^{m}\left(K w_{j} E\left[U^{i}(X)\right]+1\right)\right]-1\right\},
$$

де $E\left[U^{i}\left(x_{j}\right)\right]=\int_{x \min }^{x \max } U_{j}\left(x_{j}\right) f\left(x_{j}\right) d x$;

$f\left(x_{i}\right)$ - функція (закон) розподілу щільності імовірності $j$-го $(j=1,2, \ldots, m)$ одиничного критеріального показника (параметра) $x_{j}$;

$$
U_{j}\left(x_{j}\right) \text { - функція споживчої цінності для } j \text {-го }
$$
$(j=1,2, \ldots, m)$ одиничного критеріального показника $x_{j}$; де $x_{j}$ - необхідний рівень $j$-го критеріально- 
го показника $(j=1,2, \ldots, m)$;

$$
\omega_{j} \text { - ваговий коефіцієнт кожного } j \text {-го }
$$

$(j=1,2, \ldots, m)$ критеріального показника $\sum_{j=1}^{m} \omega_{j}=1$;

$K$ - постійна нормалізації.

Сукупність усіх методів, використовуваних для технологічних процесів, виробничою системою $P$, можуть бути використані для об'єктів обробки $A$. Якщо об'єкт $A$ розглядається як неструктурований, то його модель включає в себе безліч $F(A)$ контурів (необхідних властивостей) і набір відносин між ними, що описуються булевої матрицею контурів $[A \times F(A)]$ оброблюваного об'єкта [12].

При моделюванні впливу системи $P$ на об'єкт $A$ математична модель системи $P$ називається моделлю виробничого середовища (системи), що включає в себе безліч $F(P)$ контурів (властивостей), що досягаються системою, і набором відносин між ними, представлених булевою матрицею контурів $[P \times F(P)]$ елементів системи і булевою матрицею $[P \times P]$ взаємозв'язку елементів $P$.

Для здійснення технологічного процесу об'єкта $A$ зі складом контурів $F(A)$ в системі $P$ необхідно, щоб:

$$
F(A) \subseteq F(P),
$$

або на логічному рівні опису:

$$
F(A)=F(P)^{\wedge} F(A) .
$$

Модель виробничого середовища у вигляді автоматизованого банку знань і банку даних методів можна використовувати для вирішення різних задач, в тому числі для вирішення прямої і зворотньої задачі технологічного проектування (рис. 2).

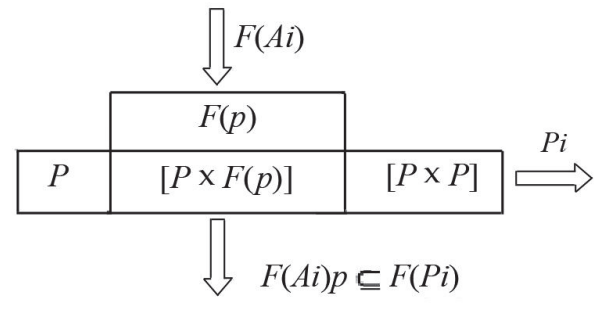

a

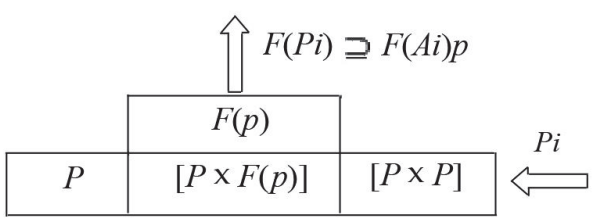

б

Рис. 2. Завдання вибору методу для технологічного процесу на моделі виробничої системи: a - пряме; б - зворотне Джерело: розроблено авторами.

При вирішенні прямої задачі (рис. 2,a) на вхід моделі надходять дані по контурах (необхідні властивості) об'єкта обробки $F(A i)$; на виході отримують набір контурів $F(P i)$ і елементів $P i$ виробничої системи, що беруть участь в забезпеченні контурів (необхідних властивостей) об'єкта $A i$, при цьому буде досягнутий повний склад контурів об'єкта $F(A i) p \subseteq F(P i)$. Очевидно, якщо $F(A i) p=F(P i)$, то виконуються умови (1) і (2), і об'єкт може бути виготовлений в даній виробничій системі.

Зворотне завдання технологічного проектування (рис. 2,б), що вирішується за допомогою тієї ж моделі виробничої системи; на відміну від прямої задачі полягає в тому, що входом $\epsilon$ набір $P i$ елементів виробничої системи, а виходом - склад контурів $F\left(P_{j}\right)$, що характеризують контури всіх можливих об'єктів $A$, які можуть бути реалізовані в заданій виробничій системі.

Розглянуті теоретичні підходи [13] створюють можливість для розробки алгоритмів інтелектуальної системи підтримки прийняття рішення (САПР) при виборі методів для технологічних процесів в інтегрованих САПР (рис. 3). За допомогою модуля логічного виведення (МЛВ) і модуля прийняття рішень (МПР) при взаємодії з САПР КІ здійснюється вибір виду та методу для забезпечення виробничих процесів, а при взаємодії з САПР ТП - вибір, проектування та інформатизація виробничих процесів. При вирішенні цих завдань МЛВ використовує банк знань БнЗн і банк конструкторсько-технологічних даних БнКТД. Формування банку знань здійснюється експертами за допомогою блоку формалізації знань (БФЗн), що дозволяє у подальшому використовувати експертну систему.

Таким чином інтелектуальна систем підтримки прийняття рішення дозволяє зробити вибір методу технологічного процесу, що має найменшу собівартість режимів роботи, що дозволяють забезпечити необхідні параметри якості, а головне дає можливість вирішувати прямі і зворотні завдання технологічного проектування.

\section{Загальна постановка задачі забезпечення процесу оптимізації технологічних процесів виробництва}

Оптимізація технологічних процесів допомагає зробити найбільш ефективний вибір оптимального варіанта в конкретній ситуації. Головними завдан- 
нями розрахунків при цьому виступають наступні:

1. Вибір оптимального критерію.

2. Визначення параметра, який буде впливати на результативність ТП.

3. Розробка $F=F(X)$ в залежності від існуючих умов моделі (наприклад, якщо визначальним параметром стала найменша собівартість, то в даному випадку цільовою буде залежність від наявних параметрів).

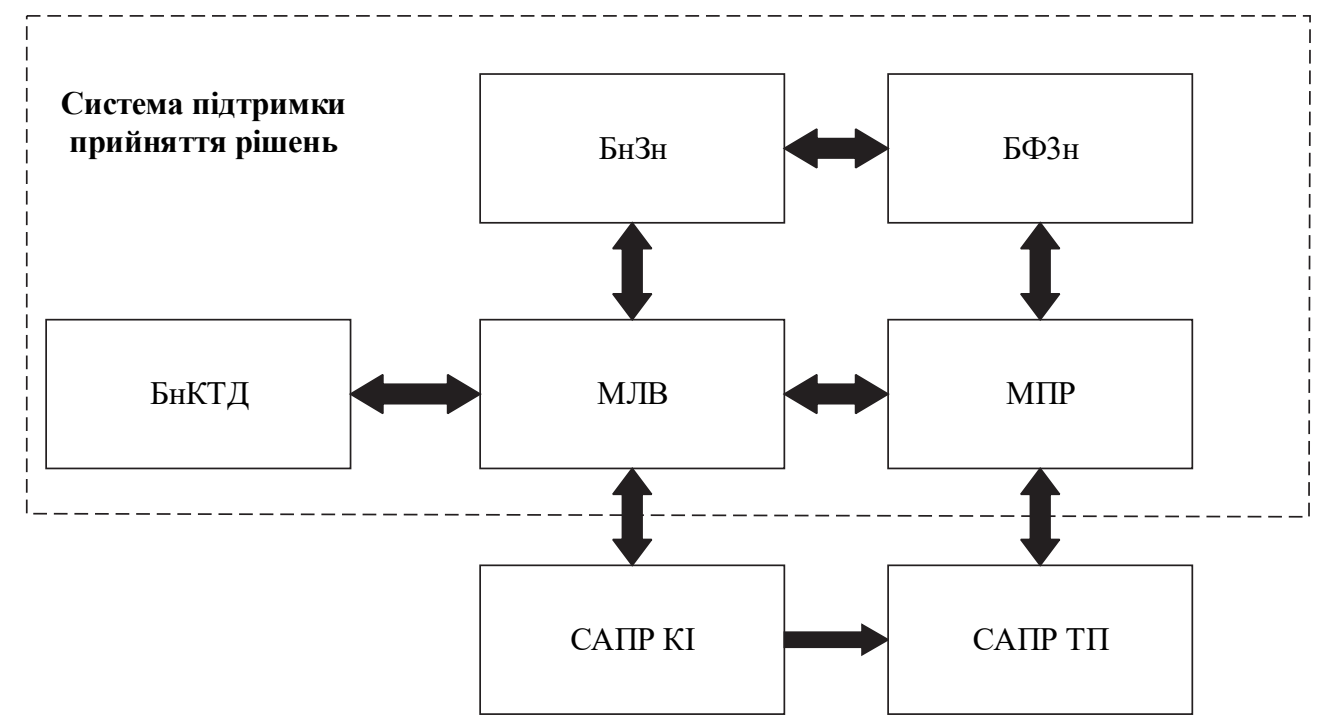

Рис. 3. Схема взаємодії інтелектуальної системи підтримки прийняття рішення при виборі методу з автоматизованими системами конструкторського і технологічного проектування Джерело: розроблено авторами.

4. Пошук оптимального рішення з обчисленням екстремуму, знаходженням найбільш підходящого для конкретної ситуації технологічного процесу.

При цьому, види оптимізації ТП (технологічних процесів) включають в себе параметричні i структурні робочі методи. Перша група - це зміна наявних значень при певній структурі, наприклад, розрахунок оптимального складу режиму використання устаткування. Щоб вирішити такі завдання, необхідно використання нелінійного або лінійного математичного програмування.

Структурна оптимізація процесу проектування пов'язана 3 підбором структури, вона працює за принципом виключення варіантів за рахунок наступного:

- втручання в уже здійснене проектування 3 метою пошуку найкращого i результативного рішення 3 певної точки зору і відповідно до заданих значень;

- уніфікація обраних варіантів.

Оптимізація параметрів для технологічного процесу вирішує завдання вибору методу, при якому найменші витрати на обчислення дадуть більший інформаційний об'ємом про необхідний процес.

Процеси знаходяться в прямій залежності від того, які саме методи будуть застосовані в роботі при пошуку найбільш результативного рішення для конкретної ситуації.

Оптимізація для технічних процесів застосовується для вибору оптимального варіанту з наявних, тобто фактично виконується пошук екстремуму для $F(X)$ за допомогою варіювання наявних проектних (заданих попередньо) значень для $X$ в межах наступної області допущення: extr $F(X), \mathrm{X} D x$, при цьому використовуються наступні параметри:

$-F(X)$ - використовувана функція;

$-X$ - вектор змінних;

- $D_{x}$ - допустима робоча область $X$.

Вибором може бути найменша собівартість, тобто найменші фінансові витрати, максимально можлива продуктивність при заданих умовах з найменшим часом, необхідним для виготовлення однієї одиниці.

Методи оптимізації технологічних процесів можуть використовувати один або кілька критеріїв, тобто можливо застосовувати різні параметри, багатокритеріальну оптимізацію. При цьому створюється один компромісний критерій, що враховує одразу декілька вибраних параметрів, так званих $E_{i}$-локальних критеріїв $\left(E_{1}, E_{2}, E_{3}, \ldots E_{r}\right)$. Для кожного такого критерію можливе вирішення завдань оптимізації розробки технологічних процесів, після чого проводиться обчислення екстремального значення для $E_{i}$ (при $i$, що дорівнює $1,2,3, \ldots, r$ ).

Рівняння відхилення для критерію можливо записати таким чином:

$$
Q_{i}=E_{i}-E_{i}^{*} .
$$

Окремо для кожного 3 них слід обчислити ваговий коефіцієнт $\lambda_{i}\left(0<\lambda_{i}<1 \quad i \quad \sum \lambda_{i}=1\right)$, що необхідно для визначення важливості параметра в 
рамках технологічного процесу. Для запису компромісного критерію застосовується адитивна функція $Q=\sum Q_{i} \lambda_{i}$. Тільки після цього вирішується оптимізація параметрів процесу. Для вирішення можуть застосовуватися різні методи, включаючи імітаційні, аналітичні, комбіновані.

Аналітичні методи оптимізації технологічного процесу виробництва припускають застосування засобів математичного програмування.

Імітаційна оптимізація управління технологічними процесами передбачає роботу в реальних умовах, створення імітаційної моделі, основа якої дає можливість вибрати найкращий варіант ТП. При оцінках застосовуються способи виключення, вибору відповідної моделі, що дозволяє досягти заданого критерію.

Комбінований метод передбачає використання окремих зазначених прийомів, об'єднання аналітичного і імітаційного методів в один, що дозволяє досягти оптимального результату. Такий спосіб застосовується при певних умовах і необхідності отримання найбільш точного результату.

В якості прикладу розглядається схема руху інформації в процесі оптимізації технологічного процесу.

Для обраної схеми є доцільним проведення оптимізації для ланцюгів технологічних операцій, 3 обранням результату, що матиме кращий результат згідно ваговій функції.

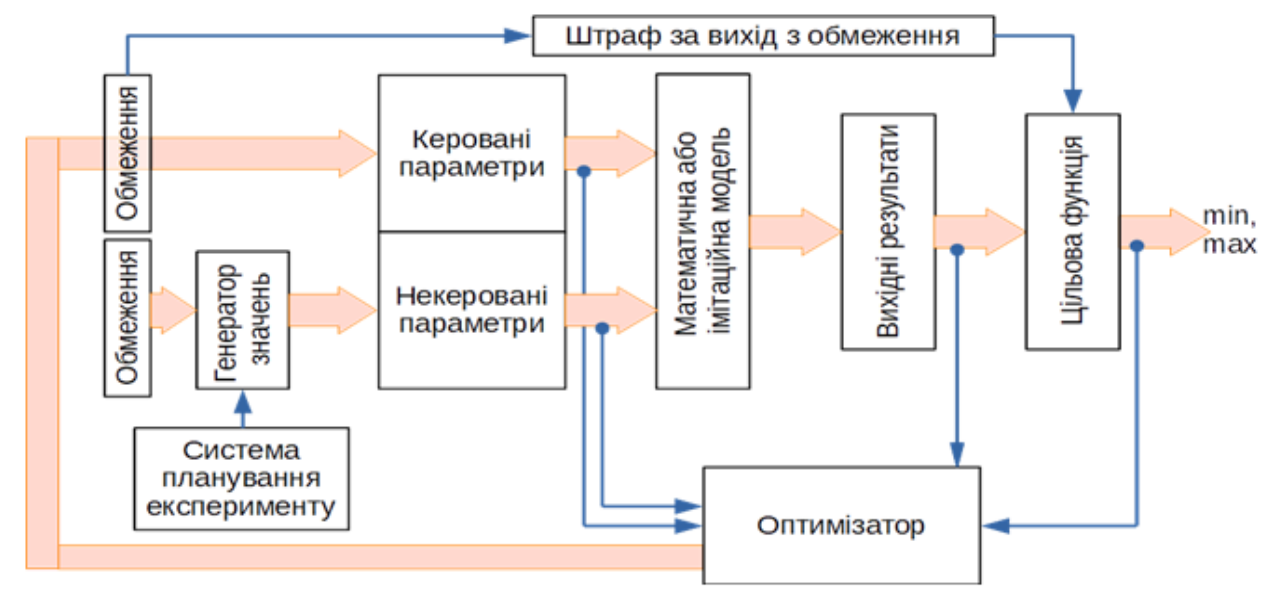

Рис. 4. Схема руху інформації в процесі оптимізації технологічного процесу Джерело: розроблено авторами.

Як видно зі схеми руху інформації (рис. 4), кожна технологічна операція повинна відокремити наступні вектори величин:

$\vec{X}$ - контрольовані величини процесу, для цих величин існують обмеження; $x_{\min , i} \leq x_{i} \leq x_{\max , i}$;

$\vec{V}$ - відомі але не контрольовані величини процесу;

$\vec{Z}$ - невідомі та не контрольовані величини;

$\vec{R}$ - випадкові величини, що впливають на процес;

$\vec{Y}$ - параметри, які досягаються в процесі технологічної обробки.

Для вказаних величин технологічного процесу

$€$ рівняння (3), де параметри процесу $\vec{X} €$ шуканою величиною:

$$
\vec{Y}=F(\vec{X}, \vec{V}, \vec{Z}, \vec{R}),
$$

Однак для технологічного процесу, який складається з ланцюга технологічних операцій, рівняння (3) перетворюється в систему рівнянь (4):

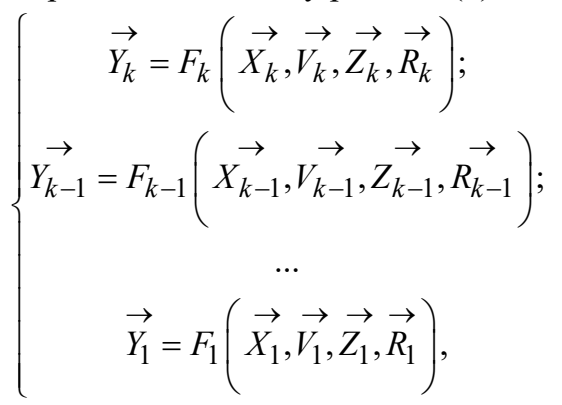

де результати попередньої технологічної операції можуть бути частково або повністю входити як параметр наступної технологічної операції, тобто:

$$
\vec{X}_{i} \cap \vec{Y}_{i-1} \neq 0 .
$$

На практиці невідомі та випадкові параметри не враховують, або допускають їх використання, як випадкові величини.

У разі наявності переліку таких випадкових параметрів, визначити межі зміни керованих величин за допомогою методів або аналітичного оцінювання відхилення результату, або використавши повно 
факторний експеримент, при змінюванні лише величин, які входять до $\vec{Z}$ та $\vec{R}$.

\section{Висновки}

Дослідження, проведені в даній роботі, дозволили провести розробку моделі системи підтримки технологічних процесів 3 використанням хмарних інформаційних технологій. В рамках цього були отримані наступні результати.

1. Було проаналізовано труднощі автоматизації проектування технологічних процесів, пов'язані головним чином 3 тим, що завдання проектування технологічних процесів не мають в даний час формальних методів вирішення. Тому для здійснення технологічного проектування було проведено розробку формалізації технології (або ії частини), тобто провести заміну (перетворення) змістовних пропо- зицій математичним апаратом.

В результаті даною формалізації було запропоновано схему руху інформації в процесі оптимізації технологічного процесу.

2. Було розроблено модель реалізації структури технологічного процесу, для якої було визначено основні вхідні параметри: перелік параметрів, які впливають на процес; перелік параметрів, які $є$ результатом процесу; перелік керованих параметрів; перелік некерованих параметрів; перелік невідомих параметрів; деталізована структура технологічного процесу з розділенням параметрів та результатів.

Таким чином зроблена у даній роботі формалізація проблеми підтримки технологічних процесів у хмарних сервісах дозволяє у подальшому оптимізувати високотехнологічні процеси підприємств різного масштабу з використання хмарних інформаційних технологій.

\section{Список літератури}

1. Смирнов А. А., Смирнова Т. В., Дреев А. Н., Дудан А. В. Оптимизация технологического процесса восстановления и упрочнения поверхностей с заданными характеристиками в виде облачного сервиса. Вестник Полоцкого государственного университета. 2020. № 3. С. 50-61.

2. Попов М. Е., Абухарб М. Система поддержка принятия решения при выборе метода упрочняющей обработки деталей машин в интегрированных САПР. Вестник Донского государственного технического университета. 2011. № 11(3). С. 333-342.

3. Скрипка К. И., Зенкин М. А. Экспертная система автоматизированного выбора способов восстановления сработанных деталей. Вестник Житомирського дорожньо-технічного університету. 2004. № 1(28). С. 66-68.

4. Смірнова Т. В. Формалізація та реалізація структури технологічного процесу електродугового напилення для оптимізаційної експертної системи. Технічні науки та технології. 2020. № 1(19). С. 104-113.

5. Смірнова Т. В. Формування евристичних правил, бази знань та формалізація структури й правил технологічного процесу для оптимізаційної хмарної інформаційної системи. Системи управління, навігаиії та зв'язку. 2020. № 2(60). C. 101-104.

6. Смірнова Т. В., Минайленко Р. М., Доренський О. П., Сисоєнко С. В., Смірнов С. А. Хмарна автоматизована система інтелектуальної підтримки прийняття рішень для технологічних процесів. Вісник Черкаського державного технологічного університету. 2020. № 4. С. 84-92.

7. Попов М. Е. Основы САПР технологических операций упрочняющей обработки : учеб. пособие. Ростов на Дону : РИСХМ, 1987. $91 \mathrm{c}$.

8. Попов М. Е. Формализованное описание структуры базы данных методов упрочняющей обработки в интегрированных САПР. Вестник Донского государственного технического университета. 2000. № 2. С. 88-91

9. Горелова Г. В., Здор В. В., Свечарник Д. В. Метод оптимума номинала и его применение. Москва : Энергия, 1970. $200 \mathrm{c}$.

10. Попов М. Е., Попов А. М. Разработка и постановка продукции на производство на основе структурирования функции качества. Вестник машиностроения. 2000. № 7. С. 52-58.

11. Анфёров М. А., Селиванов С. Г. Структурная оптимизация технологических процессов в машиностроении. Уфа : Гилем, 1996. 185 с.

12. САПР. Типовые математические модели объектов проектирования в машиностроении : метод. указания. РД 50-464-84. Москва : Стандарты, 1985. 200 с.

13. Попов М. Е., Попов А. М. Интеграция конструкторского и технологического проектирования на основе концепции Concurrent Engineering. Вестник машиностроения. 1998. № 4. С. 41-45.

14. Вереск О. М. Технологии поддержки принятия решений. Львов : Изд-во Львов. политехники, 2013. 124 с.

15. Хох В. Д., Мелешко Е. В., Якименко М. С. Исследование методов построения экспертных систем. Системы управления, навигации и связи. 2016. № 4(40). С. 48-52.

16. Лимаренко В. В. Информационная система поддержки решений для автоматизации создания технологических процессов механообработки деталей высокоточного оборудования : дис. канд. техн. наук / В.В. Лимаренко. Харьков, 2019. 
Відомості про авторів:

\section{Смірнова Тетяна Віталіївна}

кандидат технічних наук доцент

доцент Центральноукраїнського національного

технічного університету,

Кропивницький, Україна

https://orcid.org/0000-0001-6896-0612

Пархоменко Данило Олексійович

кандидат технічних наук

старший викладач Харківського національного університету Повітряних Сил ім. І. Кожедуба, Харків, Україна

https://orcid.org/0000-0002-2254-7248

Голубець Роман Олександрович аспірант Центральноукраїнського національного технічного університету, Кропивницький, Україна https://orcid.org/0000-0003-4553-3380

Щербань Андрій Васильович аспірант Центральноукраїнського національного технічного університету, Кропивницький, Україна https://orcid.org/0000-0001-5382-1812

Багдасарян Едуард Карапетович аспірант Центральноукраїнського національного технічного університету, Кропивницький, Україна https://orcid.org/0000-0002-0423-0490
Information about the authors:

\section{Tetiana Smirnova}

Candidate of Technical Sciences Associate Professor

Senior Lecturer of Central Ukrainian National Technical

University,

Kropyvnytskyi, Ukraine

https://orcid.org/0000-0001-6896-0612

Danylo Parkhomenko

Candidate of Technical Sciences

Senior Instructor of Ivan Kozhedub Kharkiv

National Air Force University,

Kharkiv, Ukraine

https://orcid.org/0000-0002-2254-7248

Roman Holubets

Doctoral Student of Central Ukrainian

National Technical University

Kropyvnytskyi, Ukraine

https://orcid.org/0000-0003-4553-3380

Andrii Shcherban

Doctoral Student of Central Ukrainian

National Technical University

Kropyvnytskyi, Ukraine

https://orcid.org/0000-0001-5382-1812

Eduard Bahdasarian

Doctoral Student of Central Ukrainian

National Technical University

Kropyvnytskyi, Ukraine

https://orcid.org/0000-0002-0423-0490

\section{ФОРМАЛИЗАЦИЯ ПРОБЛЕМЫ ПОДДЕРЖКИ ТЕХНОЛОГИЧЕСКИХ ПРОЦЕССОВ} В ОБЛАЧНЫХ СЕРВИСАХ

Т.В. Смирнова, Д.А. Пархоменко, Р.А. Голубец, А.В. Щербань, Э.К. Багдасарян

В работе проанализированы трудности автоматизации проектирования технологических процессов, связанные главным образом с тем, что задачи проектирования технологических процессов не имеют в настоящее время формальных методов решения. Поэтому для осуществления технологического проектирования проведена разработка формализации технологии (или ее части), то есть проведена замена (преобразование) содержательньх предложений математическим аппаратом. В результате данной формализачии предложена схема движения информации в процессе оптимизации технологического процесса. Также разработана модель реализации структуры технологического процесса, для которой определены основные входные параметры: перечень параметров, которые влияют на процесс; перечень параметров, которые являются результатом прочесса; перечень управляемых параметров; перечень неуправляемых параметров; перечень неизвестных параметров; детализирована структура технологического проиесса с разделением параметров и результатов. Таким образом разработанная в данной работе формализачия проблемь поддержания технологических прочессов в облачных сервисах позволяет в дальнейшем оптимизировать высокотехнологичные процессы предприятий разного масштаба с использованием облачных информаџионных технологий.

Ключевые слова: система поддержки принятия решений, технологические прочессы, облачные сервисы.

\section{FORMALIZATION OF THE PROBLEM OF SUPPORT OF TECHNOLOGICAL PROCESSES IN CLOUD SERVICES}

\section{T. Smirnova, D. Parkhomenko, R. Holubets, A. Shcherban, E. Bahdasarian}

The paper analyzes the difficulties of automating the design of technological processes, mainly due to the fact that the tasks of technological process design do not currently have formal methods of solution. Therefore, for the implementation of technological design, the development of formalization of technology (or part of it), ie the replacement (transformation) of meaningful proposals by the mathematical apparatus. As a result of this formalization, a scheme of information flow in the process of process optimization is proposed. Also the model of realization of structure of technological process for which the basic input parameters are defined is developed: the list of parameters influencing process; a list of parameters that are the result of the process; list of managed parameters; list of unmanaged parameters; list of unknown parameters; detailed structure of the technological process with the separation of parameters and results. Thus, the formalization of the problem of support of technological processes in cloud services made in this work allows to further optimize high-tech processes of enterprises of different scales on the use of cloud information technologies.

Keywords: decision support system, technological processes, cloud services. 